\title{
Teodor Oancă, Cercetări de onomastică și dialectologie [Studies of Onomastics and Dialectology], Grafix Publishing House, Craiova, 2019, 185 p.
}

\author{
Ana-Maria Prisacaru ${ }^{\mathbb{R}^{\natural} \star}$ \\ "A. Philippide” Institute of Romanian Philology, Str. Th. Codrescu 2, 700481 Iași, Romania
}

Starting from the idea that "surnames can be regarded as linguistic documents" (p. 6), researcher Teodor Oancă gathers in this volume a number of 15 studies and scientific articles that focus mainly on onomastic and dialectological research conducted, however, in an interdisciplinary context, in relation to topics such as ethnography, semantics, sociolinguistics and word formation. This research approach, which the author embraced as early as 1974-1975 when writing his doctoral dissertation entitled Toponimia din Cîmpia Băileștiului [Toponymy from Cîmpia Băileștiului] —as he himself confesses in the Argument - was further developed in the following years, when the author compiled and published a series of remarkable studies in the field of Onomastics: Probleme controversate în cercetarea onomastică românească [Controversial Issues in the Romanian Research on Onomastics] (1996), Geografie antroponimică românească. Metodă și aplicații [Romanian Anthroponomastic Geography. Method and Application] (1998), Onomastică și dialectologie [Onomastics and Dialectology] (1999), Microsisteme antroponimice românești [Romanian Anthroponomastic Microsystems] (2016), Contribuții onomastice [Contributions to Onomastics] (2018), Dicționar de frecvență a numelor de familie din România [Dictionary of Proper Names Frequency in Romania] (editor, 2003), Dicționarul toponimic al României. Oltenia [Toponymic Dictionary of Romania. Oltenia] (collaborator), etc.

The study that opens the series of scientific contributions compiled in this volume is dedicated to anthroponymic geography: Contribuții la delimitarea ariilor dialectale cu ajutorul geografiei antroponimice [Contributions to the delimitation of dialectal areas with the help of anthroponymic geography] (p. 1223). This research method, according to which an anthroponym, especially a surname, is analyzed according to its frequency of occurrence in various administrative units (counties) is aimed at "reconsidering certain dialectal areas" ( $\mathrm{p} .12$ ) by means of recording a proper name originating from a dialectal term in an area that is much larger than its appellative basis. To provide just one such example, we shall mention the manner in which the Western dialectal area of the term agud [mulberry tree] is reconstituted. Although the term is specific to the area of Moldova, Eastern Wallachia and the county of Tulcea, only four surnames deriving from this appellative are recorded in Moldova. However, in Crișana, where the commonly used term is frăgar, the anthroponym Agud is recorded 184 times. The explanation provided by the author consists in the fact that, in the $18^{\text {th }}$ century, when surnames were institutionalized in Transylvania, Maramureș, Crişana and Banat, the word agud was still active in the dialects used in the Western part of the country. The term was subsequently replaced by the competing terms frăgar and pomniţar, yet it remained in use as a surname.

The second study, Antroponime cu consoana labială inițială $[p]$ palatalizată [Anthroponyms with Labio-palatalized Initial Consonant [p]] (p. 24-32) is based on a comparative analysis, presented in an Annex, between surnames (extracted from BDAR ${ }^{1}$ ) in which palatalization of the labial consonant [p] occurs (Chele, Cheptänaru, Chetraru, Chitaru, Chistol, etc.) and the same anthroponyms containing the unaltered initial consonant $[\mathrm{p}]$. Once again, anthroponymic geography proves useful in confirming the distribution of this phonetic phenomenon

*Email address: carpanamaria@yahoo.co.uk.

${ }^{1}$ The Romanian anthroponomastic database, created in 1994 by the researchers of the Laboratory of Onomastic Research of the Faculty of Letters, the University of Craiova by processing the electronic data provided by the County police inspectorates and the Population Registration Service (p. 11). 
in the Southern area of Oltenia ${ }^{2}$ - subject to the movement of individuals in the territory, which led to the registration of surnames with this phonetic peculiarity in non-specific areas, as well.

The classification of "the terms of origin of surnames according to their semantic features" (p. 33), in other words the identification of anthroponomastic microsystems, has been a constant preoccupation of the author ${ }^{3}$, which is also revealed in his study entitled Particularități fizice, psibice, morale și de comportament generatoare de antroponime [Physical, Psychological, Moral and Behavioural Traits Generating Anthroponyms] (p. 33-60). The author discusses both expressive and non-expressive names of people derived from nicknames, which designate the particularities announced by the title. Starting from the phrase "a pune suflet"/ "to put one's heart and soul into something", Teodor Oancă considers that the anthroponym Suflet [Soul] "designates a person who proves very skilful in everything s/he does” (p. 38). On the other hand, the phrase "a trăi pe călcîi (picior) mare" "to live the good life" inspires the researcher to regard the nicknames Boer [Boyar], Călcîi [Heel] and Picior [Leg] as synonyms, a conclusion that is rather unfounded in our opinion. Since the source of the anthroponyms (hence of the nicknames on which they are based) analyzed in this study is BDAR, which was elaborated based on data provided by the Population Registration Service, we do believe that some of the explanations advanced by the author should be regarded with some caution until they are thoroughly checked in investigations on the field (although in the case of nicknames that became surnames and then family names, the reasons for which they were chosen in order to designate a certain person can no longer be identified). For instance, Teodor Oancă claims that a colour-based nickname would indicate either "the age (Albu, Bălan), or an emotional feature (Albastru, Galben, Negru, Roşu)" (p. 37); we believe, however, that someone could be called $A l b u(l)$ [White] also because that person might have a whiter skin, not only because he or she is grey or whitehaired. On the other hand, bălan (= blond) might rather refer to a fair-haired person (it is even possible that the nickname ironically targeted a dark-haired person!). In our opinion, the association the author implies between the colours yellow and blue with certain emotions is also quite obscure. As for the colours black and red, although it is obvious that they could be associated with states of mind such as anger/sadness, respectively fury, we still believe that the author could have also considered a context in which Negru [Black] could have designated a person with darker skin and Roşu [Red] someone whose face would turn excessively red in some circumstances.

In the same register, we should mention the article entitled De la nume de unelte la nume de familie [From Names of Tools to Family Names] (p. 166172 ), in which the author discusses the possibility of establishing a micro-system of surnames derived from names of tools, specifying that their frequency of occurrence and territorial distribution depends on the degree of specialization of the respective tool (Baros [sledgehammer] - 412 recordings in BDAR vs. Ciocan [hammer] - 16991 recordings) and on the appartenance of the etymon to a certain Romanian dialect (Ilău, for instance, occurs quite frequently in Moldova, whereas the surname derived from the synonym term nicovală [anvil] is not mentioned in BDAR).

The study entitled Toponime compuse cu determinant adjectival în Cîmpia Bäileştiului [Composed Toponyms with Adjectival Determiner in Cîmpia Băileștiului] (p. 61-69) focuses on names of places recorded during toponymic investigations conducted prior to the elaboration of Dicționarului Toponimic al României. Oltenia [Toponymic Dictionary of Romania. Oltenia]. The analysis of toponymic units from the respective area reveals that the dominant formative model is made of a noun (entopic) + adjectival determiner, where the latter designates the "gentle" geography of the area ${ }^{4}$ often marking relations of toponymic differentiation (Balta Mare [The Big Puddle] vs. Balta Mică [The Small Puddle], Biserica Nouă [The New Church] vs. Biserica Veche [The Old Church], Covei $\rightarrow$ Covein Mare [The Big

\footnotetext{
${ }^{2}$ This conclusion is also confirmed by the toponymical research conducted by the author in the area of Cîmpia Băileștiului, where toponyms originating from appellatives displaying various stages of palatalization are also recorded (see Teodor Oancă, Onomastică și dialectologie [Onomastics and Dialectology], 1999).

${ }^{3}$ See, in this regard, Microsisteme antroponimice românești [Romanian Anthroponomastic Microsystems] (2016) and Contribuții onomastice [Onomastic Contributions] (2018).

4 "No adjective such as repede [fast], often recorded in the toponymy of the mountain or hill areas, is associated to hydronyms in the current toponymy of Cîmpia Băileștiului” (p. 62).
} 
Covei] vs. Coveiu Mic [The Small Covei], Desnățui $\rightarrow$ Desnățuiul Mic [The Small Desnățui]).

Another consistent study is the one discussing the relation entopic-toponym in Cîmpia Băileștiului (p. 70-84). After the presentation of the main perspectives on the narrow category of entopics, delimited by the much larger category of appellatives, the author focuses on a series of toponyms from the studied area, extrapolating the analysis to the entire area of Oltenia in order to demonstrate that some geographical terms "acquire a more specialized meaning" in certain restraint areas (p. 73), occasionally gaining a meaning that is quite the opposite of the general one. For instance, the forest-based entopic tufă, meaning "small forest/grove, bush" in Southern Oltenia enters the logical opposition mare [big] - mic/tînăr [small/young] with the entopic pădure [forest]: La Tufă "pădurice" [grove], La Tufan "pădurice" (p. 74). However, in the same area, tufă also means "stejar" [oak tree]. Tufărel, for instance, designates a "former oak grove" and Tufanu lu Mateescu indicates "an oak-tree in the vineyard" (p. 75). This transfer of meaning from a geographical term to the other is another common phenomenon specific to small areas: for example, in Southern Oltenia, the entopic ostrov [islet], with the basic meaning of "island" (Ostrovu lu Mirica "island in the Danube", Ostrovu Mare "island in the Danube"), acquires the meaning of the entopic luncă [meadow], designating in Cetate "a stretch of woodland along the Danube" (p. 84).

Two other studies discuss the origin and meaning, on the territory of Oltenia, of the appellative hotar [boundary] (Sensul apelativului hotar in sudul Olteniei [The Meaning of the Appellative Hotar (boundary) in Southern Oltenia]) and arămuc (Arămuc, rămuc - atestare și origine [Arămuc, rămuc - Attestation and Origin]). The first lexeme is assigned the meaning "limit, edge, ending" in Southern Oltenia, without cumulating, as it happens in the Northern area of the region, the meaning "the entire surface of land belonging to a village", for which the term moșie [estate] is used. The appellative arămuc is recorded for the first time by Emil Petrovici, in Zimnicea, as the answer to the question "How do you call a flock of sheep smaller than a herd?". The term was subsequently recorded in South-Eastern Oltenia as rămúc, -múce, meaning "a group of 10-25 sheep". As far as its origin is concerned, the author relates it to the Turkish term ramak "small quantity" (which does not exceed 40 units) ${ }^{5}$. The addition of the prothetic $a$ - remains, however, debatable, although the author either relates it to the contact the Romanians living on the right shore of the Danube had with the Aromanians or explains by analogy with pairs of terms that used to be in circulation with or without prothetic a (alămîie - lămîie [lemon], alăută - lăută [lute], etc.).

Numele personal din perspectivă sociolingvistică [Proper Names from a Socio-linguistic Perspective] (p. 90-116) is an extremely well-documented study on the changes of names that occurred in the period 1981-1985, requested either by the parents of the name bearer or the bearer himself/herself when reaching adulthood. Besides the changes in the marital status of the petitioner or the request to correct names that had wrong spellings in the civil registration records because of the negligence of either parents or clerks, the reasons behind name changes "mostly reflect sociocultural factors affecting the individual, his/her family or the petitioner's environment" (p. 93): eliminating diminutives and hypocorisms, replacing outdated or unattractive names, a predilection for names regarded as "more elevated", borrowing foreign names that were "fashionable" etc.

Four of the studies included in this volume deal with the analysis of anthroponymic suffixes. The first of these studies, Antroponime cu dublu sufix de apartenență [Anthroponyms with Double Appurtenance Suffixes] (p. 117-121), discusses surnames in which the Romanian patronymic suffix - escu is attached to an anthroponymic base ending in $-o v /-e v$, a suffix bearing the same family appurtenance value (Birovescu, Iancovescu, etc.). As the author explains, this double derivation was possible because the Slavonic suffix imposed by the editors of the Slavic-Romanian documents in the detriment of the Romanian - escu $u^{6}$ lost its meaning for the Romanians, so that the anthroponyms derived with $-o v /-e v$ were eventually regarded as "simple names with a consonant ending” (p. 118). With regard to the origin of this type of anthroponyms, the hypo-

\footnotetext{
5 "[...] a quantity exceeding the number 40 is the [Turkish] equivalent of kîrk, meaning «much»" (p. 88).

${ }^{6}$ In the context of the deliberate slavicization of Romanian names by the foreign deacons, we believe that the labelling of these anthroponyms as "Romanian creations" is rather inaccurate (p. 121).
} 
thesis according to which some of them could have originated from the Slavonic language (Birovescu < Bulg. Birov, Iscovescu < <Bulg. Iscovici and so on) is refuted, according to the author, by the very existence in the Romanian language of the anthroponymic bases: Bira/Biru - which also occur in names such as Biraescu/Birăescu, Birău, etc., Iscu - a name attested ever since the $17^{\text {th }}$ century (p. 118-120). We believe, however, that the presence of the same anthroponymic base in both Bulgarian and Romanian is not necessarily an argument for denying the Bulgarian origin of these anthroponymic derivates with the suffix $-o v$ (which is not a Romanian, but a Slavonic one). These Bulgarian anthroponymic derivates were subsequently added the suffix -escu, specific to the Romanian language.

The next study belonging to the series dedicated to the derivation of Romanian surnames provides a detailed analysis of the anthroponymic suffix -cea (p. 122-128). Bearing a diminutive value, this suffix is presented as being composed of $-c i u+-e a^{7}$, being primarily involved in generating "masculine names, diminutives of the names or surnames from which they were formed" (p. 124). For an accurate perspective on the frequency of this suffix in Romanian onomastics, the author emphasizes the need to distinguish between proper names formed with -cea (Balancea < Bălan, Bătrîncea < Bătrînu, T,igancea < Ţiganu) and names resulted from the derivation of Romanian or Slavonic anthroponymic bases ending in $c$ (+ vowel), respectively in $c / \check{c}$, with the suffix $-e a$ or $-a$ (Butucea < Butuc, Colacea < Colac, etc.). For the sake of an accurate analysis we believe it is also necessary to make a clear distinction between the Romanian anthroponymic derivates discussed by the author in this study and the Slavonic anthroponymic derivates in circulation in our language, as in the latter the suffix -cea may be subject to different explanations regarding its structure and origin, the most discussed hypothesis being the fact that it originates from the Slavonic $-\check{c} e$, with a diminutive value ${ }^{8}$.

The second Romanian anthroponymic suffix analyzed is -ilă (p. 129-151); it bears both an augmentative value and an expressive one, when expressing an exaggeration of the particularities of the individual it designates. With regard to the origin of this suffix, the author notes that "most options incline towards the Slavonic language" (p. 133). Although numerous, not all anthroponymic creations containing this suffix became surnames, as BDAR records just 140 such derivates from a "surname used as an unofficial family name in the $19^{\text {th }}$ century" (p. 132): Băcilă (< Baciu), Berbecilă (< Berbec), Manoilă (<Manole), etc.

Another thoroughly documented study is dedicated to the pairs of anthroponymic suffixes -aca/-aga, -eca/-ega, -ica/-iga, -oca/-oga, $-u c a /-u g a$ (p. 152-165), analyzed both from the perspective of their origin and possible inclusion in a system and by relating them to the corresponding suffixes in the common language. Moreover, the author discusses the value of the final $-a$ in the structure of these anthroponymic suffixes, ruling out its motional function, as the names of people derived with these suffixes are masculine names. The only exception is the suffix $-i c a$, where $-a$ can also be motional, when it generates feminine forms from masculine names derived with -ică: Stan - Stănică - Stänica. For all the analyzed suffixes the author provides important details regarding their origin, value and productivity in the Romanian language.

In Transhumanță și toponimie în Oltenia [Transhumance and Toponymy in Oltenia] (p. 173176) the author discusses the dynamics of minor toponymy designating the transhumance phenomenon in the context of political and socioeconomic changes that occurred throughout the years. Toponyms such as Drumu Oii / Drumu Oilor, Drumu Lînii, Drumu Ungurenilor, Drumul Munteanului or Drumu Mocanilor, recorded in Oltenia in the period of transhumance pastoralism, became less frequent starting with the $19^{\text {th }}$ century, when this practice was gradually replaced by local shepherding. As a consequence, these microtoponyms compete with and are eventually replaced by minor toponyms that were more relevant for the locals (Drumul Oii [The Sheep's Way] $\rightarrow$ Drumu Muierii [The Woman's Way], called as such because it was located in the vicinity of Dealului Muierii [The Woman's Hill]).

\footnotetext{
${ }^{7}$ The information is taken by the author from N. A. Constantinescu, Dicționar Onomastic Românesc, 1963, p. LVII.

${ }^{8}$ See Iorgu Iordan, Toponimia românească [Romanian Toponymy], 1963, p. 535. For further details regarding the etymology of this suffix, see Mic dicționar toponimic al Moldovei (structuralși etimologic). Partea 1. Toponime personale [Small Toponymic Dictionary of Moldova (structural and etymologic). Part 1. Personal Toponyms], 2014, s.v. Vrancea.
} 
In the article Antroponime hutule [Hutsul Anthroponyms] (p. 177-182), the author uses the same method of anthroponymic geography to identify the cradle of a series of Hutsul anthroponyms starting from the area in which the appellative base represented by a dialectal term was in use? Thus, based on the high frequency recorded in Northern Moldova, the author labels as Hutsul anthroponyms elements such as Boroda (< Ukr., Rus. borodá "beard", a lexeme specific to the Hutsul dialect), Cubăr (< kuhar "cook"), predominant in the county of Suceava, Strilaț/Strilețchi/Striliciuc (< strilac "hunter"), Zub (< Ukr., Rus. zub "tooth"), with its derivates $Z u b a s ̧$ and $Z u b a s ̧ c u$, more frequent in the Northern part of the country, etc.
All these studies, preceded by Argument, Bibliography and Abbreviations, and followed by a short abstract in English and Italian, are reunited in a volume substantiated on the laborious research of both Romanian toponymy, with a special focus on Cîmpia Băileștiului, and Romanian anthroponymy, especially with regard to family names, approached mainly from a perspective pertaining to anthroponymic geography. Ignoring a few shortcomings mainly derived from typing errors, we are entitled to say that this is a reference work for the readers interested in the Romanian onomastics and dialectology, especially since the author discusses various topics in the context of the complementarity of these two branches of linguistics with the fields of ethnography, semantics, morphology and sociolinguistics.

\footnotetext{
${ }^{9}$ The analysis of these appelatives from which nicknames and subsequently surnames recorded in BDAR derived is built on information taken from Ioan Pătruț, Fonetica graiului huţul din Valea Sucevei [The Phonetics of the Hutsul Dialect in Valea Sucevei] (1957).
} 